\title{
MOBBING AND WORK ALIENATION: SUPPORT FROM COLLEAGUES AS A MODERATOR
}

\author{
Ayşe Gönül DEMİREL* \\ Ayşe Begüm ÖTKEN** \\ Özlem KUNDAY***
}

\begin{abstract}
The purpose of this study is to investigate the relationship between mobbing and work alienation with a special emphasis on the role of support from colleagues. A questionnaire based on Leymann Inventory of Psychological Terror scale which measures mobbing and Mottaz (1981) 21-item that measures work alienation was used to assess this relationship. The sample constitutes of 182 professionals employed in various companies in Istanbul. The findings supported the main research hypothesis and showed that mobbing influences work alienation. Support from colleagues has a moderating role in the relationship between mobbing and work alienation. The results of this research provide important insight to existing theory and have practical implications for managers in terms of the relationship between mobbing and work alienation.
\end{abstract}

Keywords: Mobbing, work alienation, social support.

$\ddot{O} \mathbf{z}$

\section{İşyerinde Psikolojik Taciz ve İşe Yabancılaşma İlişkisi Üzerinde İş Arkadaşlarından Alınan Desteğin Rolü}

$\mathrm{Bu}$ çalışmanın amacı psikolojik taciz ve işe yabancılaşma arasındaki ilişkiyi ve bu ilişki içerisinde çalışma arkadaşlarından alınan desteğin rolünü incelemektir. Mobbing Leymann'ın geliştirdiği Inventory of Pscyhological Terror işe yabancılaşma ise Mottaz'ın geliştirdiği İşe Yabancılaşma ölçekleri kullanılarak ölçülmüştür. Çalışmanın örneklemi İstanbul'da farklı şirketlerde çalışan 182 beyaz yakalı çalışandan oluşmaktadır. Yapılan analizler sonucunda

\footnotetext{
* Asst.Prof.Dr., Yeditepe University, Department of Business Administration, 06800, ANKARA, TURKEY, gonuld@yeditepe.edu.tr

** Asst.Prof.Dr., Yeditepe University, Department of Business Administration, 06800, ANKARA, TURKEY, begum.otken@yeditepe.edu.tr

*** Asst.Prof.Dr., Yeditepe University, Department of Business Administration, 06800, ANKARA, TURKEY, okunday@yeditepe.edu.tr
} 
araştırmanın hiptezleri doğrulanmış ve psikolojik tacizin işe yabancılaşmayı etkilediği ortaya konulmuştur. Ayrıca, çalışma arkadaşlarından alınan desteğin de şartlı değişken rolü oynadığı sonucuna ulaşılmıştır. Her ne kadar psikolojik taciz son dönemlerde sıklıkla çalışılan konularda biri olsa da çalışmanın sonuçları psikolojik taciz ile işe yabancılaşma arasındaki ilişki açısından yöneticilere önemli bir bakış açısı sunmaktadır.

Anahtar Sözcükler: Psikolojik taciz, işe yabancılaşma, sosyal destek.

\section{INTRODUCTION}

Albeit mobbing is an old phenomenon, it was not depicted and methodically researched until the beginning of the 1980s. The term mobbing was popularized during the 1980s especially through the research done by Heinz Leymann. According to Leymann (1990), mobbing is a kind of long term hostile behavior detected in employees at heir workplaces. It is not an easy task to identify the existence of mobbing since these hostile behaviors at the workplace can be considered as quite usual interactive behaviors. However, the systematic and long term repetition of them starts the mobbing process and can result in dangerous results for both the victim and the organization.

Given the importance of mobbing and its potentially negative influence on employee and organizational well-being, it is not surprising that this topic has attracted the attention of researchers worldwide. Some researchers focus on the behaviors that describe mobbing and the frequency of these behaviors in the organization (Ayoko, et.al., 2003; Leyman, 1992) and some focus on the personality of the victim and the person who is likely to engage in mobbing (Ayoko, et.al., 2003). A growing body of research has showed the negative and sometimes devastating consequences that mobbing can have on both the employees and on the organization. Research demonstrates that mobbing may have a wide range of physical and psychological symptoms, including stress and anxiety about work, nervousness, depression, loss of confidence, low levels of job satisfaction and decreased organizational commitment (Leymann, 1990; Vartia and Hyyti, 2002). Despite these harmful influences, there may be some other negative consequences that mobbing may have. Work alienation may be among these consequences.

First introduced by Karl Marx, work alienation has attracted the interest of many researchers (Kanungo, 1983). Work alienation represents a generalized, unenthusiastic outlook toward the world of work that indicates a low level of engagement in the work role (Kobasa, et.al., 1982). Employees feel that they have no control and autonomy over the job they do, they don't see their work as 
important and valuable or make self-sacrifices in terms of their needs and interests (Kanungo, 1990). These feelings of powerlessness, meaninglessness and self-estrangement which are considered as the three dimensions of the concept result in work alienation. Understanding the antecedents and consequences of work alienation is quite critical for improving the quality of work life and organizational effectiveness. In the past decade, a number of studies have been conducted to advance our understanding of this complex interpersonal behavior mobbing and also work alienation separately. However, most of the research about work alienation and mobbing is conducted in Western cultures. Thus, investigating the concepts and the possible relationship between mobbing and work alienation in Eastern countries would make important contributions.

With this in mind, the purpose of this study is to understand the relationship between mobbing and work alienation. Additionally, it is thought that support from colleagues will have an important role in this relationship. If employees get support from their colleagues, it is expected that mobbing will not have an influence on work alienation. Since colleagues are seen as a source of support and assistance, their help and support would weaken the influence of mobbing on feelings of lack of control and autonomy over the work and selfsacrifices concerning their needs and interests.

\section{MOBBING}

Mobbing at the workplace is first defined by work psychologist Heinz Leymann. According to Leymann (1996) mobbing "delineates negative communicative actions, directed against an individual by one or several others, and occurring very often and over a longer period of time, thereby characterizing the relationship between perpetrator and victim..." Another definition to mobbing by Leymann is as follows (Leymann, 1996): “...Mobbing is given if one or more of 45 exactly described actions occur at least once a week over a period of half a year or more..." Leymann (1996) stresses that the actions mentioned in the definition above may also occur outside of a mobbing process; they constitute mobbing only if the three criteria of duration, repetition, and negative intention are met.

Several other terms are used to define this form of negative workplace behavior. Mobbing is commonly used in France and Germany (Leymann, 1990; Zapf, et.al., 1996). In the USA, "aggression" (Baron and Neuman, 1998) and "emotional abuse" (Keashly, 2001) have been used. The term "workplace bullying" is used primarily by researchers in Australia (Sheehan, 1999), the United Kingdom (Rayner, 1997) and Northern Europe (Einarsen and Skogstad, 
1996). English and Australian researchers have used the term 'bullying'; American researchers have used both 'mobbing' and 'bullying'; No general agreement or clear consensus exists on the definition of workplace 'bullying', and several other terms have been used interchangeably. The term bullying means harassing, offending, socially excluding someone, or negatively affecting someone's work task. Bullying is an escalation process in the course of which the person confronted ends up in an inferior position and becomes a target of systematic negative social acts whereas, mobbing is considered to be an act of aggression and an emotional assault in work organizations. As can be seen, these definitions are not dissimilar; actually, they are on a continuum. Perhaps, because bullying was originally used in the context of educational institutions, mobbing was purposely used to discriminate education from other types of organizations. They can be explained as hostile, harmful behaviors in any given workplace in any part of this world. Thus, mobbing is a universal fact, and it has a negative impact on emotional well-being of any member of any organization (Yahyagil and Aktaş, 2010).

When several definitions of the term are analyzed at least five significant features of the phenomenon are distinguishable. First, mobbing involves negative or hostile behaviors occurring systematically and over time. Second, there must be an imbalance of power between the target of the mobbing and the mobber. Third, usually, both superiors and co-workers are regarded as potential mobbers. Fourth, intentionality or even enjoyment of negative behaviors has sometimes been included in the definition. The aggressor tries to maximize the effects and minimize the risks. Fifth, various kinds of negative acts are involved. These have been classified as the manipulation of 1) the victim's reputation, 2) the victim's performance of work tasks, 3) the victim's communication with co-workers, 4) the victim's social life, and as 5) physical assaults, or the threat of physical violence. Some researchers exclude physical violence from mobbing strategies (Yahyagil and Aktaş, 2010). Sexual harassment could be regarded as a manifestation of mobbing or as a separate problem. It has been regarded as the kind of mobbing in which sexuality is utilized as a means of oppression. In contrast to the persistent and long-term nature of most negative behaviors called mobbing, a single negative act of a sexual nature in the workplace can be regarded as sexual harassment (VartiaVäänänen, 2003).

Prior research on mobbing has focused primarily on defining workplace bullying behavior, (Saunders, et.al., 2007), identifying the behavioural forms that bullying can take (Ayoko, et.al., 2003; Baron and Neuman, 1998; Bjorkqvist, et.al., 1994), measuring the frequency with which bullying behaviours occur in organisations (Einarsen and Raknes, 1997; Hogh and Dofradottir, 2001; Leymann, 1992; Salin, 2001), documenting the negative 
consequences that bullying can have on both the target and the organisation (Ayoko et.al., 2003; Bjorkqvist et.al., 1994; Einarsen and Raknes, 1997; Leymann, 1990; Price-Spratlen, 1995; Vartia and Hyyti, 2002), identifying who is likely to participate in workplace bullying interactions as the target and as the bully (Ayoko et.al., 2003; Keashly, et.al., 1994).

Mobbed persons evaluate their work environment in generally negative terms and more negatively than persons who have not been mobbed (Zapf et.al., 1996). Mobbed employees might have less control over their work hours and face higher demands for co-operation than non-mobbed employees. A Finnish study (Vartia, 1996) showes that mobbed employees reported less control over their work, less influence and less clarity of work goals. Vega and Comer (2005) state that "the demoralization [mobbing] victims suffer can create toxic working environments and impair organizational productivity."

Leymann (1990) in his research observes long-term hostile and aggressive behaviors among employees. Psychological violence at work is a basic organizational problem which emerges upon a combination of all psychological factors, causing tension and an atmosphere of conflict in the organization, causing disorder in the organization and negatively affecting job satisfaction and labor peace. Should this situation last for a long period; it is inevitable that the individual will be propelled out of the organization and business life. Mobbing is a process which starts when the person becomes the target of a disrespectful and malign behavior. Initially emerging as hostility of one or several persons against one or several persons, organizational psychological violence results in alienation of the victim firstly towards himself/herself and then towards his/her environment and towards his/her work. The process starts with carelessness about the work, weariness, intimidation, low performance and results in resignation.

\section{WORK ALIENATION}

Work alienation has been considered as a central concept in sociology and psychology literature for a long time. Management practitioners and organizational theorists have also showed an interest in the topic more recently (Kanungo, 1983). Understanding the antecedents, consequences and core of the concept is thought as an important way in enhancing both organizational effectiveness and quality of work life (Kanungo, 1990).

Work alienation was first proposed and defined by Karl Marx. He defines alienation as the estrangement of individual from the output of his/her labor as well as from the work process, his/her colleagues, and ultimately 
himself/herself. Basically, Marx suggests that when the production process is mechanized and the control over the wages and behavior increases, the capitalist system enforces workers to sell their labor in order to survive and to desist from their willingness to exhibit free and self-directed production. This leads to work alienation (Kanungo, 1983). In other words, work alienation occurs when the individual has no control over the work process and the work output. Following Marx, Weber focuses on alienation quite similar to Marx. They both proposed that it is very likely for workers to experience work alienation when their achievement, responsibility and autonomy needs are not satisfied by the work environment (Kanungo, 1990). More recently, Moch (1980) defines work alienation as an attitude or a condition in which the individual cares little about work, shows little energy at work, and works primarily for extrinsic rewards. In other words, work alienation can be described as work conditions that separate the employee from the enjoyment of work products, work processes, social interaction, and realization of talents (Cheung, 2008).

Early research considers alienation as a unidimensional concept which is quite similar with Marx's theory, but in 1950s and 1960s a multidimensions of the construct have developed. The most widely used multidimensionalization of the concept belongs to Seeman in the literature. Seeman (1971) suggests powerlessness, meaninglessness, self-estrangement, normlessness and isolation as the five dimensions of alienation. Others who have focused on work alienation as a multidimensional approach have basically used variations of Seeman's dimensions as well. Powerlessness represents the lack of control over the occurrence of the outcomes, or reinforcements he/she seeks. It can be equated with a lack of job autonomy and participation and this means that employees have limited freedom within their task domain. Meaninglessness exists when workers feel that they contribute little to the overall production process and they are not able to see how their role fit into this big picture. Selfestrangement can occur when the work process is perceived as alien to the individual, and the individual has no contributions to it (Mottaz, 1981). Work alienation shows that specific work processes and procedures give individuals limited autonomy and prevent them from participation (Seeman, 1971). When these conditions occur, employees may experience powerlessness, meaninglessness and self-estrangement (Mottaz, 1981). These dimensions are central to the concept of work alienation and this study uses work alienation as a multidimensional concept including these three dimensions.

Many attempts were made to investigate and predict the antecedents and consequences of work alienation. Some theorists (e.g. Marx, Braverman) focus on structural conditions and technology at the structural level that generate alienation. Researchers examining work alienation at the structural level use models that reflect the influence of work structure characteristics on job 
autonomy and participation (Kakabadse, 1986; Zeffane and Macdonald, 1993). At the individual level, research has focused on the perceptions and feelings of individuals within specific work conditions and relationships (Kakabadse, 1986). This study focuses on work alienation at the individual level and examines the relationship between mobbing and work alienation and also adds the role of support that employees get from their colleagues.

\section{SUPPORT FROM COLLEAGUES}

The presence of social support has been shown to affect stressfull life events as well as many physical and psychological illnesses (Brown and Harris, 1978; Gottlieb, 1981; Holahan and Moos, 1981; Wilcox, 1981). One of such a stressfull event is experiencing mobbing and it is very important here to understand the role of social support.

Henderson and Argyle (1984) state that research findings indicate the importance of the source of social support. They indicate that "the major effect of social support on health derives from work supervisors and spouses, with relatively little effect for work colleagues, while perceived work stresses are correlated with support from both supervisors and co-workers, but not nonwork support" (House and Wells, 1978 in Henderson and Agryle, 1985). According to the findings of La Rocco, et.al., (1980), support from colleagues provide more buffering than than supervisor or home support. Peer or support from colleagues has also emerged as a significant element in several research studies on retention (Ellet and Millar, 2004; Nissly, et.al., 2005). On the other hand, some studies found no significant influence regarding peer support (Jacquet, et.al., 2008; Weaver, et.al., 2007).

One of the suggestions proposed by researchers to preventing or managing mobbing is to include the provision of social support (Branch, et.al., 2007). As Quine (1999) proposes the provision of social support "may function as a buffer against stress by providing resources to enable [targets] to cope (Quine, 1999: 231) and thereby reduce the impact of mobbing.

Many researchers (Lewis and Orford, 2005; Matthiesen, et.al., 2003; Leymann and Gustafson, 1996) indicate that the absence of social support is crucial to the failure of mobbing victims to cope with the situation. Lewis and Orford (2005), in their study on women who experienced mobbing, found that 'being heard' and 'believing in you' were among the most important elements to a sense of support. However, seeking social support is a proactive behaviour and thus not likely to be performed by someone feeling helpless and victimized (Lee, 1997). The findings of a study by Lewis (2004) showed that academicians 
who experienced mobbing felt intense feelings of shame which may result in avoiding to seek social support.

Mobbing has many negative results for both the organization as well as employees. One of these negative outcomes can be work alienation because employees facing mobbing will have an increased feeling of meaninglessness, will contribute little to the work process and thus loose the control over their work. Also, the reinforcement that the mobbed employee finds in his/her job will be negatively effected. However, there is an expected moderating effect of the presence of social support that the mobbed employee gets from his/her colleagues in the organization. For mobbed employees who are getting support from colleagues, the influence of mobbing on work alienation will be lower than who do not get any social support.

Based on the literature, the following hypotheses were derived:

H1: There is a significant influence of mobbing on work alienation.

H2: Support from colleagues moderates the influence of mobbing on work alienation. The influence of mobbing on work alienation will be less for employees getting support from colleagues.

\section{METHOD}

\subsection{Sample}

220 questionnaires were distributed, but 182 of them turned back. The response rate is $82 \%$ Sample consisted of 182 white collared employees working in Istanbul. They work in different sectors such as finance, pharmaceutical, education, tourism and technology. Data were collected by convenience sampling. The companies of the respondents are reached conveniently.

\subsection{Procedure}

Questionnaires were face to face administered by the researchers. Before distributing the questionnaires, respondents were given brief explanation about the confidentiality and the procedure of the study. For each participant the procedure took approximately 20 minutes. Questionnaires were distributed and collected within three months. 


\subsection{Measurement Instruments}

The questionnaire used for this study consists of five parts. The first part included brief information about the study and demographic questions such as gender, marital status, education level, tenure, number of years spent in work life and sector of respondents.

In the second part of the questionnaire respondents were given the following definition developed by the Leymann (1996): "Mobbing is an emotional violence. It is a psychological violence that involves hostile and unethical communication which is directed in a systematic way by one or few individuals mainly towards one individual who is pushed into a helpless and defenseless position". Then, respondents were asked if they perceived themselves as being exposed to mobbing. Additionally, they were asked whether they have any friends being exposed to mobbing at the workplace and from whom they mostly see mobbing behaviors. Since the participants were Turkish people and they were not native English speakers, definition was given and questions were asked in Turkish

Third part of the questionnaire included Leymann Inventory of Psychological Terror scale which measures mobbing. The scale is developed by Leymann. It includes 45 items and these items are presented in 5 thematic sections: social relationships (no possibility to communicate, verbal aggression, criticism, etc.), exclusion (isolation, rejection, etc.), job situations and tasks (no tasks, too many tasks, uninteresting tasks, humiliating tasks, tasks inferior or superior to skills, etc.), personal attacks (attacks on opinions or origins, rumors, gossiping, etc.), and physical violence and threats of physical violence (including sexual harassment). Sampe items include "I have been forced to do humiliating jobs", "My presence has been ignored", I have been given difficult work assignments far above my capacity" and "I have been physically threaten". A six point Likert scale was used ranging from "always" (6) to "never" (1). As a result of the reliability analysis Cronbach alpha is found as .96

Work alienation was measured using the 21-item scale which was developed by Mottaz (1981). The scale represents three dimensions of alienation such as powerlessness, meaninglessness and self estrangement. Sample items include: "I have good deal of freedom in the performance of my daily task", "Sometimes I am not sure I completely understand the purpose of what I'm doing", "My work is a very self rewarding experience". Individuals responded to each statement on a six point scale ranging from "strongly disagree" (1) to "strongly agree" (6). As a result of the reliability analysis Cronbach alpha is found as .80 
Support from colleagues is measured by four items using Co-worker Social Support Scale developed by Caplan, et.al., (1975). Sample item include "I can rely upon my coworkers when things got tough at work". A six point Likert scale ranging from "strongly disagree" (1) to "strongly agree" (6) was used. Cronbach alpha is found as .91.

\section{RESULTS}

\subsection{Descriptive Statistics}

The sample consists of 76 females and 107 males. $65 \%$ of the sample was between the ages of 22-29 years. $74 \%$ of the sample has a university degree, and $21.1 \%$ has a postgraduate degree. The work experience of the respondents varied between 1 and 20 years. $74 \%$ of the respondents had been working for 1-4 years in their organization. The mean tenure in the current organization is 3.5 years. This shows that majority of the sample is quite new in their organization.

As it is mentioned before, respondents are asked if they perceived themselves as being exposed to mobbing whether they have any friends being exposed to mobbing at the workplace and from whom they mostly see mobbing behaviors. 57 of the respondents $(n=184)$ think that they are subjected to mobbing behaviour.77 of the respondents believe that their colleagues are subjected to mobbing behavior. 49 of the respondents believe that their "managers" apply mobbing.

\subsection{Factor Analyses}

In order to find the factor structures of mobbing, factor analysis using principal components solution with varimax rotation was used. Any item with a factor loading less than .50 or loading to more than one factor was discarded from the analysis. Factors with Eigenvalues 1.00 or more were taken into consideration in total variance explained. 
Table 1: Factor Analysis Results of Mobbing Scale

\begin{tabular}{|c|c|}
\hline \multirow[t]{2}{*}{ FACTOR 1: Physically damaging actions } & \multirow{2}{*}{ Factor Loadings } \\
\hline & \\
\hline The victim is sexually harassed & 0.858 \\
\hline The victim is physically attacked & 0.836 \\
\hline The victim is physically threaten & 0.822 \\
\hline The victim suffers physically threats & 0.814 \\
\hline The victim is physically attacked with serious consequences for his health & 0.805 \\
\hline The victim is given dangerous work assignments & 0.796 \\
\hline The victim is forbidden to talk & 0.787 \\
\hline The victim is sexually attacked & 0.752 \\
\hline The victim is terrorized by means of phone calls & 0.740 \\
\hline Colleagues prevent the victim to communicate & 0.734 \\
\hline The victim is made fun of his physical disabilities & 0.727 \\
\hline People at work make fun about the ethnic heritage or nationality & 0.702 \\
\hline The victim suffers written threats & 0.687 \\
\hline The victim is isolated in a room far away from others & 0.686 \\
\hline The victim is said to have a mental illness & 0.679 \\
\hline Slanders and lies about the victim are used at work & 0.679 \\
\hline The victim suffers verbal threats & 0.662 \\
\hline Victim is wrongly accused & 0.618 \\
\hline The victims voice, gestures, way of moving are imitated & 0.507 \\
\hline FACTOR 2: Over- Criticism & \\
\hline The victim is reviled using degrading terms & 0.733 \\
\hline The victim is deprived of any activity when being at work & 0.600 \\
\hline People at work make fun about the victims personal life & 0.596 \\
\hline The aggressor tries the victim to go through psychiatric exams & 0.566 \\
\hline The victim suffers verbal attacks regarding his political and religious beliefs & 0.551 \\
\hline The victim is controlled and his job performance is tracked for those with bad intentions & 0.543 \\
\hline FACTOR 3 : Humiliation & \\
\hline The aggressor or mobber gives the victim no possibility to communicate & 0.628 \\
\hline The victim is given humiliating work assignments & 0.587 \\
\hline Colleagues are forbidden to talk to the victim & 0.560 \\
\hline FACTOR 4: Inappropriate occupational activities & \\
\hline The victim is continuously given new work assignments & 0.794 \\
\hline The victim is given difficult work assignments far above his capacity & 0.658 \\
\hline The victim is given meaningless work assignments & 0.649 \\
\hline The victim suffers verbal attacks regarding work assignments & 0.647 \\
\hline Victims decision are questioned & 0.532 \\
\hline The victim is silenced or continuously interrupted & 0.512 \\
\hline FACTOR 5 Intrusion of Personal Life Issues & \\
\hline The victim suffers verbal attacks regarding personal life & 0.815 \\
\hline Gossiping about the victim & 0.668 \\
\hline $\begin{array}{ll}\text { Kaiser-Meyer-Olkin Value: } .932 & \text { df : } 903 \\
\text { Bartlett Significance Value: } .000 & \text { Chi-Square Value: } 7570,319 \\
\end{array}$ & \\
\hline
\end{tabular}


45 items of mobbing measure were entered into factor analysis. KaiserMeyer-Olkin (KMO) value was found as .930. This result marked the homogeneous structure of the variables and the result of Bartlett Test (.000, Chi-Square: 8017.180, df: .820) showed that the variables were suitable for factor analysis. Few rotations were made to obtain the best representation of the data and items were left out of the analysis that did not have large factor loadings and that had crossloadings. The remaining 39 items were loaded on six factors explaining $69.24 \%$ of the total variance. F6 (m17, m39) did not give sufficient reliability (alpha $=0.5843$ ) and factor analysis is rerun with the remaining variables. The results of the second factor analysis gave 5 factors with high reliabilities. Alpha F1 $=0.9701$, alpha F2 $=0.8929$, alpha F3 $=0.7050$, alpha F4=0.8661 and alpha F5 $=0.7117$. The results of the factor analysis are shown in Table 1.

Factor analysis is run for work alienation scale as well. Kaiser-MeyerOlkin (KMO) value was found as .816. This result marked the homogeneous structure of the variables and the result of Bartlett Test (.000, Chi-Square: 1382.276, df: .120) showed that the variables were suitable for factor analysis. Few rotations were made to obtain the best representation of the data and items were left out of the analysis that did not have large factor loadings and that had crossloadings. The remaining 16 items were loaded on four factors explaining $64.827 \%$ of the total variance. The Reliability Analysis of each factor are quite sufficient with alpha F1 $(14,13,10,8)=0.820$, alpha F2 $(19,21,17,18)=0.812$ , alpha F3 $(11,16,12,15,9)=0.736$, alpha F4 $(5,6,1)=0.721$. The resulting factors were labeled and the results of the factor analysis are shown in Table 2. 
Table 2: Factor Analysis Results of Work Alienation Scale

\begin{tabular}{lc}
\hline FACTOR1: Misperception about work role & F var : 17.876 \\
& Factor Loadings \\
\hline I understand how my work fits in with the work of others here. & .866 \\
I understand how my work role fits into the overall operation of this organization & .841 \\
My work is really important and worthwhile. & .647 \\
My work is a significant contribution to the successful operation of the organization & .517 \\
\hline FACTOR 2: Work attributes & $\%$ var : 17.574 \\
\hline My work is a self-rewarding experience & .836 \\
My work is interesting and challenging & .780 \\
My work provides me a sense of personal fulfillment & .666 \\
I have little opportunity to use my real abilities and skills in the type of ....... & .620 \\
\hline FACTOR 3 : Concerns about work & $\%$ var : 16.098 \\
\hline I often wonder what the importance of my job really is & .739 \\
I often feel that my work counts for very little around here & .625 \\
I do not feel a sense of accomplishment in the type of work I do & .620 \\
16My salary is the most rewarding aspect of my job & .613 \\
Sometimes I am not sure I completely understand the purpose of what I'm doing. & .604 \\
\hline FACTOR 4: Lack of control over work activities & \\
\hline I am not able to make changes regarding my job activities & .863 \\
My daily activities are largely determined by others & .793 I \\
have a godd deal of freedom in the performance of my daily task & .605 \\
\hline Kaiser-Meyer-Olkin Value: .816 df : 120 & \\
Bartlett Significance Value: .000 Chi-Square Value: 1382. 276 & \\
\hline
\end{tabular}

\subsection{Multiple Regression Analyses}

Multiple Regression Analysis is run several times in order to test the first main hypothesis of the research.

$\mathrm{H}_{1}$ : There is a significant influence of mobbing on work alienation.

Independent variables of the concept mobbing (physically damaging actions, overcriticism, humiliation, inappropriate occupational activities and intrusion of personal life issues) are first checked for normality and then nonparametric correlations are run for detecting any possible multicollinearity and no multicollinearity was found. Linearity tests were also done and the model was ready for multiple regression. Core concept work alienation has four variables namely misperception about work role, work attributes, concerns about work and lack of control over work activities. 
$\mathrm{H}_{1 \mathrm{a}}$ : At least one of the independent variables explains significantly the variance in FA1.

$\mathrm{H}_{1 \mathrm{~b}}$ : At least one of the independent variables explains significantly the variance in FA2.

$\mathrm{H}_{1 \mathrm{c}}$ : At least one of the independent variables explains significantly the variance in FA3.

$\mathrm{H}_{1 \mathrm{~d}}$ : At least one of the independent variables explains significantly the variance in FA4.

\subsection{Results of the Multiple Regression Analysis to test $\mathbf{H}_{1 \mathrm{a}}$}

The first model proved statistically significant with $\mathrm{F}=4,906$ and $\mathrm{p}=0,000$. T-statistics and related $\mathrm{p}$ values indicated that physically damaging actions (FM1), humiliation (FM3), inappropriate occupational activities (FM4) and intrusion of personal life issues (FM5) did not contribute significantly to the model and are left out for a second run of multiple regression. Final model proved significant with $\mathrm{F}=45,528$ and $\mathrm{p}=0,000$. $\mathrm{R}$ square is 0,201 which indicated that over-criticism (FM2) explain misperception about work role (FA1) at $\% 20$ with 0.000 significance level. When $t$ statistics and $\mathrm{p}$ values are checked it shows that $\mathrm{fm} 2(\mathrm{t}=6,747$ and $\mathrm{p}=0.000)$ contributes to the model significantly.

\subsection{Results of the Multiple Regression Analysis to test $\mathbf{H}_{1 \mathrm{~b}}$}

The first model proved statistically significant with $\mathrm{F}=3,073$ and $\mathrm{p}=0,012$. T-statistics and related $\mathrm{p}$ values indicated that physically damaging actions (FM1), humiliation (FM3), inappropriate occupational activities (FM4) and intrusion of personal life issues (FM5) did not contribute significantly to the model and are left out for a second run of multiple regression. Final model proved significant with $\mathrm{F}=18,525$ and $\mathrm{p}=0,000$. $\mathrm{R}$ square is 0,093 which indicated over-criticism (FM2) explains work attributes (FA2) at \%10 with 0.000 significance level. When $\mathrm{t}$ statistics and $\mathrm{p}$ values are checked it shows that $\mathrm{fm} 2(\mathrm{t}=-4,304$ and $\mathrm{p}=0.000)$ contributes to the model significantly.

\subsection{Results of the Multiple Regression Analysis to test $\mathrm{H}_{1 \mathrm{c}}$}

The first model proved statistically significant with $\mathrm{F}=10,276$ and $\mathrm{p}=0,000$. T-statistics and related $\mathrm{p}$ values indicated that humiliation (FM3), inappropriate occupational activities (MF4) and intrusion of personal life issues (MF5) did not contribute significantly to the model and are left out for a second 
run of multiple regression. Final model proved significant with $\mathrm{F}=44,581$ and $\mathrm{p}=0,000$. $\mathrm{R}$ square is 0,198 which indicated that physically damaging actions (MF1) and over-criticism (MF2) explains concerns about work (FA3) at \%19 with 0.000 significance level. When $t$ statistics and $\mathrm{p}$ values are checked it shows that $\mathrm{fm} 1(\mathrm{t}=1,078$ and $\mathrm{p}=0.283)$ did not contribute to the model significantly. Regression is run for the third time. Final model proved significant with $\mathrm{F}=44,581$ and $\mathrm{p}=0.000$. $\mathrm{R}$ square is 0.198 which indicated that over-criticism (FM2) explains concerns about work (FA3) at \%19 with $\mathrm{p}=0.000$ significance. Beta coefficients are shown in table below.

\subsection{Results of the Multiple Regression Analysis to test $\mathbf{H}_{1 \mathrm{~d}}$}

The first model proved statistically significant with $\mathrm{F}=8,385$ and $\mathrm{p}=0,000$. T-statistics and related $\mathrm{p}$ values indicated that physically damaging actions (MF1), humiliation (FM3), and intrusion of personal life issues (MF5) did not contribute significantly to the model and are left out for a second run of multiple regression. Second model proved significant with $\mathrm{F}=22,459$ and $\mathrm{p}=0,000$. $\mathrm{R}$ square is 0,200 which indicated that over-criticism (FM2) and inappropriate occupational activities (MF4) explain lack of control over work activities (FA4) at \%20 with 0.000 significance level. When t statistics and $\mathrm{p}$ values are checked it showed that $\mathrm{fm} 2$ and $\mathrm{fm} 4(\mathrm{t}=2,300$ and $\mathrm{p}=0.023 ; \mathrm{t}=2$, 809 and $\mathrm{p}=0.006$ ) contribute to the model significantly. Beta coefficients are shown in table below.

As a result of these multiple regression analysis, first hypothesis of the study stating "There is a significant influence of mobbing on work alienation" is supported.

\subsection{Testing the Moderating Role of Support from Colleagues}

Each factor regarding the work alienation (4 factors) was treated as a dependent variable in the models. Therefore, several analyses were carried out with 4 factors as dependent variables, mobbing (5 factors) and support from colleagues (overall) as independent variables. Number of hierarchical regression analysis was conducted one for each interaction term of the independent and the moderator variable in order to test moderating role between mobbing and work alienation factors (Hypothesis 2). In hierarchical regressions, independent, moderator and interaction terms, which are calculated by multiplying the independent variable and moderator variable, were entered into analysis at successive steps.

All variables had been centered before they were entered into the analysis (West, et.al., 1996). First, each independent and moderator variables tested for normality. None of the variables were distributed normally, so median of the 
variables was used. Median of the each independent variable was subtracted from every single value score (for example, physically damaging actions (MF1) - median of physically damaging actions) and so do the moderator variables (for example, support from colleagues - median of support from colleagues). Then, the interaction terms were calculated by multiplying new independent variable scores and moderator variable scores (for example, physically damaging actions (MF1)* support from colleagues). A significant change in the variance explained by the regression step and a significant beta coefficient for an interaction term constitutes a moderating effect.

In the first step of the hierarchical regression analysis, an independent variable, following the independent variable moderator variable was entered. In the third step, the interaction term of the two variables was entered into the analysis. The results of the hierarchical regression analysis were tabulated in Table 3.

Table 3: Results of the Hierarchical Regression Analysis

Dependent Variable: Misperception about work role

\begin{tabular}{|c|c|c|c|}
\hline Independent Variables & Step 1 & Step & Step 3 \\
\hline Over-criticism & $.448 *$ & $.317 *$ & .156 \\
\hline Support from Colleagues & $*$ & -.312 & -.308 \\
\hline Over-criticism*Sup.from Colleagues & & & $-.222 *$ \\
\hline $\mathbf{R}^{2}$ & .201 & .281 & .304 \\
\hline Adjusted R2 & .197 & .273 & .292 \\
\hline $\mathbf{R}^{2}$ change & .201 & .080 & .023 \\
\hline $\mathbf{F}$ & $45.528 *$ & $35.189 *$ & $26.072 *$ \\
\hline \multicolumn{4}{|c|}{ Dependent Variable: Misperception about work role } \\
\hline Independent Variables & Step 1 & Step 2 & Step 3 \\
\hline Inappropriate occupational activities & $.320 *$ & $.183 *$ & .105 \\
\hline Support from Colleagues & & $-.379 *$ & $-.361 *$ \\
\hline \multicolumn{3}{|c|}{ Inappropriate occupational activities*Sup.from Colleagues } & $-.203 *$ \\
\hline $\mathbf{R}^{2}$ & .102 & .227 & .261 \\
\hline Adjusted R $\mathbf{R}^{2}$ & .097 & .219 & .240 \\
\hline $\mathbf{R}^{2}$ change & .102 & .125 & .034 \\
\hline $\mathbf{F}$ & $20.659 *$ & $26.469 *$ & $21.092 *$ \\
\hline
\end{tabular}

Support from colleagues was found to moderate the relationship between over-criticism (MF2) and misperceptions about work role (FA1). Over-criticism has a significant positive influence as a single factor on perceptions about work role, but beta coefficient of over-criticism decreased in each step $(\beta=.448$; $\mathrm{p}<.05$ to $\beta=.317 ; \mathrm{p}<.05)$. In the third step, when the interaction term entered into the analysis, the significance of over-criticism on perceptions about work role disappeared. Since the interaction term is significant at the third step, it has found to have moderating role between over-criticism (MF2) and perceptions 
about work role perceptions about work role (FA1). Same moderating role is found between inappropriate occupational activities (FM4) and misperceptions about work role (FA1). The positive and significant influence of inappropriate occupational activities inappropriate occupational activities (FM4) on misperceptions about work role (FA1) has decreased in each step and with the inclusion of the interaction term significant influence has disappeared. Support from colleagues is also significant in each step. No other significant relationship was found between other mobbing factors and misperception about work role (FA1) with respect to the moderating effect of support from colleagues.

The same steps were followed for the second factor of work alienation. No significant moderating influence was found between physically damaging actions (MF1), humiliation (MF3) and work attributes (FA2). The results are shown in Table 4.

Table 4: Results of the Hierarchical Regression Analysis

\begin{tabular}{|c|c|c|c|}
\hline \multicolumn{4}{|c|}{ Dependent Variable: Work Attributes } \\
\hline Independent Variables & Step 1 & Step 2 & Step 3 \\
\hline Over-criticism & .305 & $* .197 *$ & -.006 \\
\hline Support from Colleagues & & $-.255^{*}$ & $-.250 *$ \\
\hline Over-criticism*Sup.from Colleagues & & & $-.282 *$ \\
\hline $\mathbf{R}^{2}$ & 093 & 146 & 183 \\
\hline Adjusted R ${ }^{2}$ & 088 & 137 & .170 \\
\hline $\mathbf{R}^{2}$ change & 093 & .054 & .037 \\
\hline \multirow[t]{2}{*}{$\mathbf{F}$} & $18.525^{*}$ & $15.431 *$ & $13.392 *$ \\
\hline & \multicolumn{3}{|c|}{ Dependent Variable: Work Attributes } \\
\hline Independent Variables & Step 1 & Step 2 & Step 3 \\
\hline Inappropriate occupational activities & $.279 *$ & $.180^{*}$ & .090 \\
\hline Support from Colleagues & & $-.273 *$ & $-.252 *$ \\
\hline \multicolumn{3}{|c|}{ Inappropriate occupational activities* Sup.from Colleagues } & $-.234 *$ \\
\hline $\mathbf{R}^{2}$ & .078 & .142 & 187 \\
\hline Adjusted R ${ }^{2}$ & .073 & .133 & .173 \\
\hline $\mathbf{R}^{2}$ change & .078 & .065 & 045 \\
\hline \multirow[t]{2}{*}{$\mathbf{F}$} & $15.252 *$ & $14.938^{*}$ & $13.730^{*}$ \\
\hline & \multicolumn{3}{|c|}{ Dependent Variable: Work Attributes } \\
\hline Independent Variables & Step 1 & Step 2 & Step 3 \\
\hline $\begin{array}{l}\text { Intrusion of personal life } \\
\text { issues }\end{array}$ & .126 & .045 & -.058 \\
\hline Support from Colleagues & & $-.327 *$ & $-.223^{*}$ \\
\hline \multicolumn{3}{|c|}{ Intrusion of Personal life issues*Sup.from Colleagues } & $-.273^{*}$ \\
\hline $\mathbf{R}^{2}$ & .016 & 116 & 164 \\
\hline Adjus & 010 & .106 & .150 \\
\hline $\mathbf{R}^{2}$ change & .016 & .100 & 047 \\
\hline $\mathbf{F}$ & $2.920 *$ & $11.832 *$ & $11.670^{*}$ \\
\hline
\end{tabular}


Support from colleagues was found to moderate the relationship between overcriticism (MF 2) and work attributes factor of work alienation. Overcriticism has a significant positive influence as a single factor on work attributes, but beta coefficient of overcriticism decreased in each step $(\beta=.305$; $\mathrm{p}<.05$ to $\beta=.197 ; \mathrm{p}<.05$ ) and in the third step, when the interaction term entered into the analysis, the significance of overcriticism on work attributes disappeared. Since the interaction term is significant at the third step, it has found to have moderating role between overcriticism and work attributes. Same moderating role is found between inappropriate occupational activities (FM4) and work attributes (FA2) and intrusion of personal life issues (FM5) and work attributes (FA2). The positive and significant influence of inappropriate occupational activities (FM4) and intrusion of personal life issues (FM5) on work attributes has decreased in each step and with the inclusion of the interaction term significant influence has disappeared. Support from colleagues is significant in each step.

The same steps were followed for the third factor of work alienation and no significant moderating influence was found between physically damaging activities (FM1), humiliation (FM3) and concerns about work (FA3). On the other hand, it has been found that support from colleagues has a moderating influence between overcriticism (MF2) and concerns about work role (FA3); inappropriate occupational activities (MF4) and concerns about work (FA3) and intrusion of personal life issues (FM5) and concerns about work (FA3). Results are tabulated in Table 5. 
Table 5: Results of the Hierarchical Regression Analysis

Dependent Variable: Concerns about work

\begin{tabular}{|c|c|c|c|c|}
\hline Independent Variables & Step 1 & Step 2 & & Step 3 \\
\hline Overcriticism & $.445 *$ & $.399 *$ & & $.256^{*}$ \\
\hline Support from Colleagues & & $-.107 *$ & & -.104 \\
\hline Overcriticism*Sup.from Colleagues & & & & $-.199 *$ \\
\hline $\mathbf{R}^{2}$ & .198 & .207 & & .225 \\
\hline Adjusted R $\mathbf{R}^{2}$ & .193 & .198 .212 & & \\
\hline $\mathbf{R}^{2}$ change & .198 & .009 .018 & & \\
\hline \multirow[t]{2}{*}{$\mathbf{F}$} & $44.581 *$ & $23.510 *$ & & $17.367 *$ \\
\hline & \multicolumn{4}{|c|}{ Dependent Variable: Concerns about work } \\
\hline Independent Variables & Step 1 & Step 2 & & Step 3 \\
\hline Inappropriate occupational activitie & & $.393 *$ & .338 & $* .246^{*}$ \\
\hline Support from Colleagues & & $-.153 *$ & & -.131 \\
\hline \multicolumn{4}{|c|}{ Inappropriate occupational activities*Sup.from Colleagues } & $-.240 *$ \\
\hline $\mathbf{R}^{2}$ & .155 & .175 & & .222 \\
\hline Adjusted R $\mathbf{R}^{2}$ & .150 & .166 & & .209 \\
\hline $\mathbf{R}^{2}$ change & .155 & .020 & & .047 \\
\hline \multirow[t]{2}{*}{$\mathbf{F}$} & $33.136 *$ & $19.092 *$ & & $17.035 *$ \\
\hline & \multicolumn{4}{|c|}{ Dependent Variable: Concerns about work } \\
\hline Independent Variables & Step 1 & Step 2 & & Step 3 \\
\hline Intrusion of personal life issues & & $.306 *$ & $.253 *$ & $.171 *$ \\
\hline Support from Colleagues & & $-.213 *$ & & -.130 \\
\hline \multicolumn{3}{|c|}{ Intrusion of personal life issues*Sup.from Colleagues } & & $-.218 *$ \\
\hline $\mathbf{R}^{2}$ & .094 & .136 & & .166 \\
\hline Adjusted R $\mathbf{R}^{2}$ & .089 & .127 & & .152 \\
\hline $\mathbf{R}^{2}$ change & .094 & .042 & & .030 \\
\hline $\mathbf{F}$ & $18.699 *$ & $14.182 *$ & & $11.908 *$ \\
\hline
\end{tabular}

Support from colleagues was found to moderate the relationship between over-criticism (MF2) and concerns about work factor 3 of work alienation. Over-criticism has a significant positive influence as a single factor on concerns about work (FA3). Since the interaction term is significant at the third step, it has found to have moderating role between over-criticism (MF2) and concerns about work (FA3). Same moderating role is found between inappropriate occupational activities (MF4) and concerns about work (FA3) and intrusion of personal life issues (MF5) and concerns about work (FA3). The positive and significant influence of inappropriate occupational activities (MF4) and intrusion of personal life issues (FM5) on concerns about work (FA3) has decreased in each step and with the inclusion of the interaction term significant influence has disappeared. Support from colleagues is significant in each step. Support from colleagues has no moderating role between any mobbing factors 
and the fourth factor of work alienation which is lack of control over work acitivities.

Following the probing procedure recommended by Aiken and West (1991), further regression analysis was run. The sample was split at the median into two groups of high and low support from colleagues and additional regression analysis was conducted. However, there were no valid cases for high support from colleagues model. So, further analysis could not be used. As a result of the moderator analysis, second hypothesis stating "Support from colleagues moderates the influence of mobbing on work alienation. The influence of mobbing on work alienation will be less for employees getting support from colleagues" is partially supported.

\section{DISCUSSION}

Mobbing has become a very popular issue in the occupational research area. It has recently been paid attention more and more in the academic and business settings. Mobbing may present itself as behaviors, words, acts, gestures, or writings that affect personality, dignity, physical, and psychological integrity (Gül, 2009) and may force individuals leave the work environment. It may harm both the individual and the organization. Alienation of employees from their work and work environment can be one of these harmful consequences. Work alienation represents the extent to which a person is disengaged from the world of work. This research specifically looks at the influence of mobbing on work alienation. It was also thought that support gained from colleagues might moderate the relationship between mobbing and work alienation. The findings supported the main research hypothesis and showed that mobbing influences work alienation.

Results of the regression analysis show that the mobbing factor, over criticism (FM2) explains the variance in two work alienation factors, namely misperception about work role factor (FA1) and work attributes. When the employee's religious beliefs, political opinions and work role requirements are criticized, he can not see the importance and significance of his work and he can not perceive how his work role fits in with the work of his colleagues and the overall organization. Moreover, it is found that the influence of over criticism on perception about work role is moderated by support from colleagues. When the victim gets support from colleagues, the influence of over criticism on employee's lack of belief in the importance and significance of his work are reduced. Support from colleagues also moderates the relationship between inappropriate occupational activities factor of mobbing and perception about work role factor of work alienation. This outcome also appears when the 
employee is given meaningless work assignments; his decisions are questioned and continuously given new work assignments. In this case, colleagues are seen as source of assistance and support in the work environment and their support reduces this negative relationship.

The regression results also indicate that the over criticism factor of mobbing influences the concerns about work factor of work alienation as well as the control over work factor of work alienation. Over criticizing the victim's religious beliefs, political opinions and work role requirements, he wonders what the importance of his job really is, does not feel a sense of accomplishment, and is not sure about the purpose of his job. On the other hand, being over criticized also influences the control over work factor. When the victim is over criticized, he feels that his daily activities are largely determined by others, has no freedom in his daily task performance and is not able to make any changes to his job activities. This, in total increases his feeling of being not in control over his own tasks related to his job. Another result of the regression analysis is that the inappropriate occupational activities factor of mobbing explains the variance in the control over work activities factor of work alienation. When the victim is continuously given new and difficult work assignments far above his capacity, or is given meaningless work assignments, his feeling of being not in control over his own tasks related to this job is influenced.

Concerning the moderator analysis, results showed that support from colleagues moderates the relationship between inappropriate occupational activities (FM4) and work attributes (FA2): intrusion of personal life issues (FM5) and work attributes (FA2). This shows that when employee perceives that he gets assistance from the colleagues, they don't force him for work assignments and they show support, being given new assignments from the manager, being criticized for his work and personal life and being questioned for his decisions don't influence him to see his work as meaningless, uninteresting and not challenging. Getting support from colleagues influences his unpleasant experience in the work setting and prevents him to feel detached from his work.

Support from colleagues also moderates the relationship between over criticism (FM2) and concerns about work (FA3); inappropriate occupational activities (FM4) and concerns about work (FM2); intrusion of personal life issues (FM5) and concerns about work (FA3). When employee gets support and assistance from his colleagues even he is continuously criticized for his position requirements, political opinions and religious beliefs, personal life or given undervalued work assignments, questioned for his decisions he doesn't feel lack of control over his work activities or unaware of his personal talents. 
Although there is no research that addresses the relationship between mobbing and work alienation, there are indirect support for the results of this study from the literature. Results of this study show that mobbing at the workplace may have negative influences on employees' work attitudes, and feelings about work. This is in parallel with the study of Vartia. As Vartia (1996) reported, mobbed employees report less control over their work, less influence and less clarity of work goals. Vega and Comer (2005) also stated that mobbing victims can create toxic work environments and impair organizational productivity. When employees suffer from mobbing at their workplace, they may feel meaninglessness and powerlessness about their work.

However, it should be noted that colleagues are important source of support and assistance for an employee. This study emphasized the importance of social support from colleagues and found that support moderates the relationship between mobbing and work alienation. Many researchers (Lewis and Orford, 2005; Matthiesen, et.al., 2003; Leymann and Gustafson, 1996) indicated that the absence of social support is crucial to the failure of mobbing victims to cope with the situation. Support and help gained from them help employee not to have unpleasant feelings about his job, help him to believe in his talents and find a meaning and importance in the work he does. Even though he experiences hostile and psychological terrorization, getting support from colleagues weakens this unpleasant situation and its negative influences on work. This study also showed that employees mostly see mobbing behaviors from their managers (26.8\%). This is followed by colleagues (14.8).

\subsection{Limitations}

This study is not without its limitations. First of all convenience sampling method has been used. Data is basen on self-reported questionnaires. Use of questionnaire as an only data collection method is a limitation.Data can be collected from different sources using interviews or observation. If sample size has been more than 200 a confirmatory factor analysis would also have been possible for the questionnaire. Sample size could be proportional between male and female respondents and thus allowing for a meaningful gender differences analysis with respect to the influence of mobbing on work alienation.

\subsection{Suggestions for Future Research}

Mobbing has become a very popular topic and many people are now realizing that they are being mobbed in their work by their managers, supervisors, colleagues, and also subordinates as well. In this sense, several academic studies are trying to describe and explain certain relationships and consequences and describe profiles of the victim and the mobber. Generally, 
questionnaire is preferred as a data collection tool and victims are asked whether they confronted with certain behaviors. This may create a common method variance. In order to avoid from this bias, future research may use interviews with victims or observation as a supplementary data collection method.

Future research about mobbing may focus on the relationship between mobbing and other employee attitudes and organizational variables. These may include characteristics of organizational culture which promotes mobbing, behaviors and personality characteristics of the manager or colleagues who use mobbing and the influence of mobbing on work engagement, job involvement, organizational citizenship behavior, and burnout can be identified. These results may provide important insights both for academicians and manager to prevent this psychological terrorism and create a peaceful and productive working environment.

Future research may also look into which motivational type better survives the psychological damages brought on by mobbing and work alienation, whether there is a difference between achievement, affiliation and power oriented people.

Work alienation is a fruitful concept in understanding employees' feelings and psychological states toward their work. However, there are scarce empirical studies linking this concept to various organizational variables. The majority of the studies focus on job related variables such as the degree of autonomy or control the employees have on their work, the extent of job division, the repetitiveness of work that is being done, the amount of feedback the employees receive about the outcomes and the proximity of employees to the final service or product. Nevertheless, other studies focus on technology being used, organizational structure and leadership styles. In this framework, this study will present a new perspective by examining mobbing and work alienation. Future research about work alienation should pay attention to the association of work alienation to other organization related variables and other employee attitudes.

\subsection{Managerial Implications}

This study has revealed several important implications especially for managers in organizations. The results show that one of the many results of mobbing is its negative influence on work alienation. Victims that are being mobbed are more likely to experience work alienation. Work alienation causes that the employee feels more and more estranged to his work and thus his performance can decrease. On the other hand, low performance of employees 
will result in an overall drop in organizational performance. To prevent this, it is necessary to identify and possibly prevent mobbing. One way to prevent as well as create awareness to mobbing is by providing training to employees. Such training will make them understand what mobbing is, what to do when it is present, and discourage employees from mobbing others.

\section{REFERENCES}

Aiken, L.S. and S.G. West (1991) Multiple Regression: Testing and Interpreting Interactions, London: Sage Publications.

Ayoko, O.B., V.J. Callan and C.E. Hartel (2003) "Workplace Conflict, Bullying, and Counterproductive Behaviors", International Journal of Organizational Analysis, 11, 283-301.

Baron, R.A. and J.H. Neuman (1998) "Workplace Aggression-The Iceberg Beneath the Tip of Workplace Violence: Evidence of its Forms, Frequency, and Targets", Public Administration Quarterly, 21, 446-464.

Branch, S., S. Ramsay and M. Barker (2007) "Managers in the Firing Line: The Contributing Factors of Workplace Bullying by Staff, an Interview Study", Journal of Management and Organization, 13(3), 264-281.

Brown, L. and T. Harris (1978) Social Origins od Depression, London: Tavistock.

Bjorkvist, K., K. Bjorkqvist, K. Osterman and M. Hjelt-Back (1994) “Aggression among University Employees”, Aggressive Behavior, 20, 173-184.

Caplan, R.D., S. Cobb, J.R.P. French, R.U. Harrison and S.R. Pinneau (1975) "Job Demands and Worker Health", U.S. Department of Health, Education, and Welfare Publication, 75-160, Institute for Social Research, Washington DC: U.S. Government Printing Office.

Cheung Chau-Kiu (2008) "Lagged Harm of Work Restructuring and Work Alienation to Work Commitment", International Journal of Employment Studies, 16(2), 170-207.

Einarsen, S. and A. Skogstad (1996) "Bullying at Work: Epidemiological Findings in Public and Private Organizations", European Journal of Work and Organizational Psychology, 5, 185-201.

Einarsen, S. and B. Raknes (1997) "Harassment in the Workplace and the Victimisation of Men", Violence and Victims, 12, 247-263. 
Ellet, A. and K. Millar (2004) "Professional Organizational Culture and Retention in Child Welfare: Implications for Continuing Education for Supervision and Professional Development", International Journal of Continuing Social Work Education, 7(3), 30-38.

Gül, H. (2009) “An Important Psychological Risk in Occupational Health: Mobbing”, Preventive Medicine Bulletin, 8(6), 515-520.

Gottlieb, B. (1981) Social Networks and Social Support, Beverly Hills: Sage Publications.

Henderson, M. and M. Argyle (1985) "Social Support by Four Categories of Work Colleagues: Relationships between Activities, Stress, and Satisfaction", Journal of Occupational Behavior, 6, 229-239.

Hogh, A. and A. Dofradottir (2001) "Coping with Bullying in the Workplace", European Journal of Work and Organizational Psychology, 10, 485-495.

Holahan, C. and R. Moos (1981) "Social Support and Psychological Distress: A Longitudinal Analysis”, Journal of Abnormal Psychology, 90, 365-370.

House J. and J. Wells (1978) "Occupational Stress, Social Support and Health", in A.McLean, G. Black and M. Colligan (ed.), Reading Occupational Stress: Proceedings of a Conference Publication, 78-140, Reported in House, 829.

Jacquet, S., S. Clark, J. Morazes and R. Whithers (2008) "The Role of Supervision in the Retention of Public Child Welfare Workers", The Journal of Public Child Welfare, 1(3), 27-54.

Kakabadse, A. (1986) "Organizational Alienation and Job Climate: A Comparative Study of Structural Conditions and Psychological Adjustment", Small Group Behavior, 17(4), 458-471.

Kanungo, R.N. (1990) "Culture and Work Alienation: Western Models and Eastern Realities”, International Journal of Psychology, 25(5/6), 795-812.

Kanungo, R.N. (1983) "Work Alienation: A Pancultural Perspective", International Studies of Management and Organization, 13 (1/2), 119-138.

Keashly, L., V. Trott and L.M. Maclean (1994) “Abusive Behaviour in the Workplace: A Preliminary Investigation”, Violence and Victims, 9, 341-357.

Keashly, L. (2001) "Interpersonal and Systemic Aspects of Emotional Abuse at Work: The Target's Perspective", Violence and Victims, 16, 233-268. 
Kobasa, S.C., S.R. Maddi and S. Kahn (1982) "Hardiness and Health: A Prospective Study", Journal of Personality and Social Psychology, 42, 168-177.

LaRocco, J.M., J.S. House and, J.R.P. Jr. French (1980) "Social Support Occupational Stress and Health", Journal of Health and Social Behavior, 21, 202-218.

Lee, F. (1997) "When the Going Gets Tough, Do the Tough Ask for Help? Help Seeking and Power Motivation in Organizations", Organizational Behavior and Human Decision Processes, 72(3), 336-363.

Lewis, D. (2004) "Bullying at Work: The Impact of Shame among University and College Lecturers", British Journal of guidance and Counselling, 32(3), 281-299.

Lewis, S. and J. Orford (2005) “Women's Experiences of Workplace Bullying: Changes in Social Relationships", Journal of Community and Applied Socail Psychology, 15, 29-47.

Leymann, H. and A. Gustafssonn (1996) "Mobbing at Work and the Development of Post-Traumatic Stress Disorders", European Journal of Work and Organizational Psychology, 5(2), 251-275.

Leymann, H. (1996) “The Content and Development of Mobbing at Work", European Journal of Work and Organizational Psychology, 5(2), 165-184.

Leymann, H. (1992) "Ways of Explaining Workplace Bullying: A Review of Enabling, Motivating and Precipitating Structures and Processes in the Work Environment", Human Relations, 56, 1213-1232.

Leymann, H. (1990) "Mobbing and Psychological Terror at Workplaces”, Violence and Victims, 5, 119-126.

Matthiesen, S., E. Aasen, G. Holst, K. Wie and S. Einarsen (2003) "The Escalation of Conflict: A Case Study of Bullying at Work", International Journal of Management and Decision Making, 4(1), 96-112.

Moch, M.K. (1980) “Job Involvement, Internal Motivation, and Employees' Integration into Networks of Work Relationships", Organizational Behavior and Human Performance, 25, 15-31.

Mottaz, C.J. (1981) “Some Determinants of Work Alienation”, Sociological Quarterly, 22(4), 515-529.

Nissly, J.A., M.E. Mor Barak and A. Levin (2005) "Stress, Social Support, and Workers' Intentions to Leave their Jobs in Public Child Welfare", Administration in Social Work, 29, 79-100. 
Price-Spratlen, LP. (1995) "Interpersonal Conflict which Includes Mistreatment in a University Workplace", Violence and Victims, 10, 285-297.

Quine, L. (1999) "Workplace Bullying in NHS Community Trust: Staff Questionnaire Survey”, British Medical Journal, 318, 228-232.

Rayner, C. (1997) “The Incidence of Workplace Bullying”, Journal of Community and Applied Social Psychology, 7, 199-208.

Saunders, P., A. Huynh and J. Goodman-Delahunty (2007) "Defining Workplace Bullying Behavior Professional Lay Definitions of Work Place Bullying”, International Journal of Law and Psychiatry, 30, 340-354.

Salin, D. (2001) "Prevalence and Forms of Bullying among Business Professionals: A Comparison of Two Different Strategies for Measuring Bullying", European Journal of Work and Organizational Psychology, 10, 425-441.

Seeman, M. (1971) "The Urban Alienations: Some Dubious Theses from Marx to Marcuse", Journal of Applied Psychology, 63, 213-218.

Sheehan, M. (1999) "Applying Strategies for Dealing with Workplace Bullying”, International Journal of Manpower, 20, 50-56.

Vartia-Väänänen, M. (2003) "Workplace Bullying - A Study on the Work Environment, Well-Being and Health", Academic Dissertation, University of Helsinki, Helsinki.

Vartia, M. and J. Hyyti (2002) "Gender Differences in Workplace Bullying among Prison Officers", European Journal of Work and Organizational Psychology, 11, 113-126.

Vartia, M. (1996) "The Sources of Bullying: Psychological Work Environment and Organizational Climate", European Journal of Work and Organizational Psychology, 52, 203-14.

Vega, G. and D. Comer (2005) "Sticks and Stones may Break your Bones, but Words can Break your Spirit: Bullying in the Workplace", Journal of Business Ethics, 58, 101-109.

Weaver, D., J. Chang, S. Clark and S. Rhee (2007) "Keeping Public Child Welfare Workers on the Job", Administration in Social Work, 31, 5-25.

West, S.G., L.S. Aiken and, J.L. Krull (1996) "Experimental Personality Designs: Analyzing Categorical by Continuous Variable Interactions", Journal of Personality, 64, 1-48. 
Wilcox, B. (1981) "Social Support in Adjusting to Marital Disruption: A Network Analysis' in B. Gottlieb (ed.), Social Networks and Social Support, Beverly Hills: Sage Publications.

Yahyagil, M.Y. and B.G. Aktas (2010) Workplace Mobbing in Turkey: The Relationship between Mobbing, Organizational Climate and Trust, Saarbrücken, Germany: Lambert Academic Publishing.

Zapf, D., C. Knorz and M. Kulla (1996) "On the Relationship between Mobbing Factors, and Job Content, the Social Work Environment and Health Outcomes", European Journal of Work and Organizational Psychology, 5, 37-215.

Zeffane, R. and D. Macdonald (1993) "Uncertainty, Participation and Alienation: Lessons for Workplace Restructuring”, International Journal of Sociology and Social Policy, 13(5/6), 22-52. 